Journal of Social Sciences (COES\&RJ-JSS)

ISSN (E): 2305-9249 ISSN (P): 2305-9494

Publisher: Centre of Excellence for Scientific \& Research Journalism, COES\&RJ LLC

Online Publication Date: $1^{\text {st }}$ July 2017

Online Issue: Volume 6, Number 3, July 2017

https://doi.org/10.25255/jss.2017.6.3.481.490

The improvement of social science learning outcomes about cooperative through two stay two stray model on students in Class IV, SDN I Karanganom, Tulungagung

\author{
Desy Natalia Shandy \\ Widayati \\ M. Zainnuddin \\ Elementary School Teacher Education, Faculty of Education, \\ Universitas Negeri Malang \\ Jl. Semarang 5 Malang, East Java, Indonesia
}

\begin{abstract}
:
This study was conducted for students who feel bored quikly when learning social science, so it causesthe students learning outcomes low. This study discusses the Two Stay- Two Stray model to improve student learning outcomes. The study employed descriptive qualiatatif research method. The results of study demonstrated an increase of the students' comprehension by the average of final grades, students learning outcomes in pre-action is $19 \%$. In the first cylcle improve to $31.25 \%$ and $56.25 \%$. In the second cycleimprove to $68.75 \%$ and $87.5 \%$. Two Stay - Two Stray can improve students learning outcomes as well as the activities of social science in the fourth grade of SDN Karanganom 1.
\end{abstract}

\title{
Keywoord :
}

Social science, improvement, two stay- to stray model

\section{Citation:}

Shandy, Desy Natalia; Widayati; Zainuddin, M. (2017); The improvement of social science learning outcomes about cooperative through two stay two stray model on students in Class IV, SDN I Karanganom, Tulungagung; Journal of Social Sciences (COES\&RJ-JSS), Vol.6, No.3, pp:481-490; https://doi.org/10.25255/jss.2017.6.3.481.490. 
Education is one of the most important aspects to improve the quality of life in the community. Therefore the world of education should be able to improve the quality through various efforts. These efforts include innovation strategies, models or methods that can trigger the students to be more active and feel happy in joining learning activities. Improving the quality of education needs a form of planning guidelines to achieve the goal of education curriculum. Curriculum that is used at this time is Education Unit Level Curriculum (KTSP) .This curriculum requires students to be active in joining learning activities. Social science is one of the subjects included in the curriculum and taught in school or educational unit.

IPS is a subject that is taught in schools from the level of elementary, junior high school, to high school. (Ahmadi (2003: 3) described "Social science is a field of study which is a fusion of several social subjects." Through this subject, students are designed to be good citizens in their social environment. The goal of Social science is to develop students' potential sensitivity towards social life, which is useful in daily life." Suradisastra et.al (1992: 91) affirmed "The goals of social science include improving knowledge, developing skills and developing attitudes and values to the students."

The results of interviews to teachers, and observations conducted on Tuesday, January 5 , 2016 in class IV, at SDN 1 Karanganom Tulungagung in the learning process of social science, obtained the data as follows. (1) the teacher make a lesson plan (LP), (2) the students do not learn in groups, (3) the learning is still centered on the teacher, because the teacher still uses the old method in teaching namely lecturing and giving assignments, so students are not inolved to be more active. The old method caused students feel bored duringf the teaching and learning process, (4) the teacher does not use the media to support the success of learning in the teaching and learning process, so the students only read the material, listen to teacher's explanation and take notes, (5) in addition, seen from the results ofpreliminary study, most of the students obtained low grade, from 16 students in the class, 13 students $(81 \%)$ got the grade below the Minimum Criteria of Mastery Learning (KKM) and the 3 students (19\%) had reached the KKM. KKM in social science at SDN 1 Karanganom is 70. The teacher also expressed an opinion that Social Science (IPS) is a difficult and boring subject, so that students feel no interest to learn IPS.

The data obtained from the observation and interviews mismatch between the theory and field data especially in learning IPS. The problem is found that students' activeness is ignored because the learning is still centered on the teacher, while the goal of learning IPS are to improve knowledge, develop the skills, and develop attitudes of the students. Then another problem is found that students' learning outcomes are still under the KKM, while one of the goals of learning IPS is to improve students' knowledge. These problems can reduce student learning outcomes significantly if there is no solution or sustainable handling.

Solutions for these problems are: (1) teachers should prepare learning activities in the form of learning devices, (2) teachers train the students to actively participate in tasks and learn in groups, (3) teachers use interesting learning models and encourage the students to learn more active and fun in their learning activities. These solutions can overcome the problems that occur, so that the students' learning outcomes can be increased.

One of the active and fun learning models is Two Stay-Two Stray (TS-TS) model. This model is one model of cooperative learning. In applying the TS-TS model, the teacher acts 
as a facilitator and organizes the course of group activities. In this learning model, students are involved in aspects of speaking, listening and writing. Students are also given the opportunity to be active and directly involved in the learning process, so it is studentcentered learning, not teacher-centered learning.

The application of TS-TS model has been done by Diyan Krisnawati in 2015, it was a research about the application of TS-TS model in learning Social science material to know the types of work in class III SDN Kolomayan 02, Wonodadi, Blitar. It resulted that the application of the TS-TS model could improve students' learning outcomes. This can be seen from the average grade of preliminary stage, cycle I, cycle II continue to increase. On the preliminary study, the average value is 54 with a percentage of $26.32 \%$, and it was included in the category of very less. In the first cycle, the average value of the class was increased to 81 with percentage of $68.42 \%$ and it was included in the category of sufficient. In cycle II, the average grade was 90 with percentage $85.25 \%$, and it was included in the category of good. Thus, the teaching and learning process by using the TSTS model can improve students' learning outcomes.

Based on the results of the research, it is necessary to conduct a classroom action research by the title "The Improvement of Social Science Learning Outcomes about Cooperative through Two Stay Two Stray Model on Students in Class IV, SDN I Karanganom, Tulungagung".

\section{Methods}

This study employed a qualitative approach with the type of Classroom Action Research (CAR). The researcher acts as a teacher and the classroom teacher acts as an observer. This study consists of a series of actions that form a cycle which is a CAR model from Arikunto. The CAR implementation procedure consists of two cycles. Each cycle is carried out according to the change that being achieved. The procedures for CAR include: planning, execution, observation, and reflection on each cycle.

This study was conducted in the Class IV of SDN 1 Karanganom, it was located at Jalan Raya Srabah No, 50 Kauman, Tulungagung in the second semester, year 2015/2016 on Social Science subject (IPS). The reason for choosing this school as the object of research, because there are several weaknesses encountered by the school, especially in the subjects of social science, that students only listen and do tasks so it causes students feel bored and have an effect on their learning result. The subjects of this study are teachers and students of Class IV in SDN 1 Karanganom, Kauman, Tulungagung. This study involves 16 students, involves 9 male students and 7 female students.

The data collection in this study consists of process data and result data. Process data include (1) teacher interview data on preliminary study, (2) teacher activity data, and (3) students activity data. The result data are: (1) students' grades data from LKK, and (2) student grade data from written test. The process of analyzing the data is guided by the steps of analyzing qualitative research data. The analysis steps consist of three simultaneous processes: data reduction, data presentation, and conclusion.

\section{Results}

Early data is about the students learning process of Class IV in SDN 1 Karanganom, it is obtained from the results of preliminary study that was conducted by the researcher on 
Tuesday, January 5, 2015. The observation was done in class IV on learning IPS material that is economic activities in various areas. During the teaching and learning activities, the researcher acted as an observer, and observed all the events in the classroom, which included teacher's activity, students' activities and students' learning outcomes.

The results of the observation during the preliminary study showed the situation in the class: (1) the teacher has not made the Lesson Plans (2) the students do not learn in groups, (3) the learning process is still teacher-centered, because the teacher is still using the old method in teaching (4) the teacher does not use the media to support the success of learning in the teaching and learning process, so that students only do reading activities, and listening to teacher explanation and taking notes, (5) in addition, in addition, seen from the results of preliminary study, most of the students obtained low grade, (6) the teacher also expressed an opinion that Social Science (IPS) is a difficult and boring subject, so that students feel no interest to learn IPS.

Cycle I was done during two meetings with the time allocation of each meeting is $3 \times 35$ minutes. Cycle I includes planning, implementation, observation and reflection. In this cycle, the researcher conducted activities such as: (1) choosing the learning materials that will be taught to the students, (2) preparing the lesson plan, (3) preparing the books as supporting learning materials, (4) preparing the instructional media, (5) preparing instruments for collecting the data and students' learning outcomes in the form of LKK, (6) preparing observation sheets, (8) preparing the camera, and (9) preparing writing test/final test.

Cycle I meeting 2, there are some students who have not participated in the discussion optimally. There are some students who are still joking with their friends. But their friends always warned, because they feel disturbed. Responsibility and courage were also increased compared to the first meeting. The sense of responsibility of the students has begun to appear when the student acts as the guest to write information for their group, and the students who served as the host are also responsible for conveying information to the guests who passed by.

The implementation of action in cycle II consists of two meetings described as follows. At the first meeting of cycle II, the material to be learnt is about the rights and obligations of cooperative members, the meaning of cooperative symbol, and cooperative management organization, using the TS-TS model. Pre-implemented activities of Teaching and Learning Process (KBM) are praying, greetings and checking the attandance list. Early activities were performed by the teachers and students held apperception by asking questions relating to the learning materials namely cooperative, by showing the mapping concept of cooperatives and material concept of cooperative. The students and teacher observe both images and do question and answer, then the teacher convey the purpose of learning.

The core learning activity began with the teacher directing students to groups as the group in the previous meeting. Previously, the teacher again explained the syntax of TS-TS model. Then, the teacher gave the envelope containing the sub-topic of the subject and LKK. Students within the groups discussed the material that has been received. The teacher gave signs when the students acted as the guest to move from group to group. Then the students move to another group. After that, the students visit. Teacher gives 8 
minutes, if it has counted to 3 , the guest has to immediately moved to another group until returning to own group. After that, the teacher asked each group to present their group's work in front of the class, and other groups have to give critique, suggestion or addition if it is not clear. The core activities ended with a presentation of group's work.

The final activity of the first learning was the students do the writing test individually and they were given time of 15 minutes. After they have finished, the teacher and students did a reflection of learning, drew conclusion and outlined the learning materials that have been learned that day.

The material that will be learnt in the second meeting of cycle II was the cooperative capital, advantages and disadvantages of Indonesian cooperatives, and school cooperatives, using the TS-TS model. Activities of pre-KBM are praying, greeting, and checking the attendance list. Early activities that was done by the teacher was held apperception by conducting question and answer relating to the learning materials about cooperative by showing the image of cooperative and conveying the purpose of learning.

The core learning activities began with the teacher directing students to groups in accordance with previous groups as in the previous meetings. Firstly, the teacher again explained the syntax of Two Stay-Two Stray model that will be used on that day. After the students have been set in groups, the teacher asked the representative of the group members to go forward and gave them an envelope containing the subject matter and LKK material. Then the students discussed with the group about the material that has been received. After the discussion with the group, the next step was visit. The teacher gave signs when the students who acted as the guest to move from group to group. Every visit, the teacher gives them time 8 minutes, if it was already counted to 3 , the guests must immediately move to another group to return to their group. After that, the teacher asked the students to discuss again the material that they have got from another group that will be presented in the future. Then, the group presented the group's work. The group presented the work in turns in front of the other groups and the other groups assigned to give critique, suggestion or addition if it was not clear. The core activities ended with a presentation of group's work.

The final activity of the first learning is the students did the writing test individually and the teacher gave them time 15 minutes. After they have finished, the teacher and students did a reflection of learning, drew conclusion and outlined learning materials that have been learned that day.

From the result of implementation of learning IPS about cooperative material through Two Stay-Two Stray learning model in cycle II, there is improvement in all aspects, namely teacher activity, student activity and student learning result. This can be attributed to several aspects, namely: (1) there is an increase in the percentage of student activity and student learning outcomes in cycle II, (2) the teacher has been able to manage and condition the class well, it can be seen from the observation of teacher activity that has increased, (3) courage, curiosity, cooperation, responsibility, speaking skill and student activity have been shown in learning activity, (4) based on the result of data analysis, it can be said that activity and students' learning outcomes of learning IPS about cooperative material can be increased through Two Stay-Two Stray model. 
The result of observation on teacher activity in the cycle I of meeting 1 was $87 \%$ then increased to $93 \%$ at the meeting 2 . As the result of observation on student activity was $80 \%$, and then increased to $87 \%$ at meeting 2 . The average grades of classical was 63 (completeness of $3.25 \%$ ), namely 5 students completed while 11 students did not complete. At the meeting 2, the average grades of classical was 69 (completeness of $56.25 \%$ ), namely 9 students completed while 7 students did not complete.

The result of observation on teacher activity in the cycle I of meeting 1 was $93 \%$, and then increased to $100 \%$ at the meeting 2 , whereas, the result of observation on the student activity achieved $87 \%$, and then increased to $93 \%$ at meeting 2 . The average grades of classical was 72 (completeness of $68.75 \%$ ) that is 11 students completed while 5 students did not complete. At the meeting 2, the average grades of classical was 79 (completeness of $87.5 \%$ ) that is 14 students completed and 2 students did not complete.

The table of data explanation during the research is presented as follows.

Table 1 Explanation of Research Data "the improvement of social science learning outcomes about cooperative through two stay two stray model on students in class IV, SDN I karanganom, tulungagung"

\begin{tabular}{|c|c|c|c|c|c|}
\hline \multirow{3}{*}{ Implementation } & \multirow{3}{*}{ Preliminary } & \multicolumn{4}{|l|}{ ACTION } \\
\hline & & \multicolumn{2}{|l|}{ Cycle I } & \multicolumn{2}{|l|}{ Cycle II } \\
\hline & & Meeting-1 & Meeting-2 & Meeting-1 & Meeting-2 \\
\hline \multirow[t]{2}{*}{ Teacher activity } & \multirow{2}{*}{-} & 13 & 14 & 14 & 15 \\
\hline & & $87 \%$ & $93 \%$ & $93 \%$ & $100 \%$ \\
\hline \multirow[t]{2}{*}{ Student activity } & \multirow{2}{*}{-} & 12 & 13 & 13 & 14 \\
\hline & & $80 \%$ & $87 \%$ & $87 \%$ & $93 \%$ \\
\hline \multirow{2}{*}{$\begin{array}{l}\text { Students' } \\
\text { learning } \\
\text { outcomes }\end{array}$} & 63 & 63 & 69 & 72 & 79 \\
\hline & $19 \%$ & $31.25 \%$ & $56.25 \%$ & $68.75 \%$ & $87.5 \%$ \\
\hline
\end{tabular}

\section{Findings}

The findings of the problem are generally obtained when the implementation of preliminary study, teachers have not made the Lesson Plan/LP, teaching and learning 
process is still teacher-centered, it can be seen from the method used by the teachers at the time, that using the method such lecturing and giving assignments. It causes students quickly feel bored during the learning. In addition, the there is no instructional media to support the process of learning activities (learning media only in the form of pictures in the supporting books of students and teachers).Thus, it can affect students' learning outcomes and student activities during the learning process.

Two Stay-Two Stray model was applied to the learning of cooperative material can improve the activity, cooperation, responsibility, courage, and speaking skills of the students during the learning activities, it can improve students' learning outcomes. This is proved by the increase of students' grades from the cycle I to cycle II. The improvement for learning outcomes focuses on affective, psychomotor and cognitive improvement.

\section{Discussion \\ The Implementation of Two stay-Two stray in Learning IPS of Cooperative Material in Class IV, SDN 1 Karanganom, Tulungagung}

The implementation of TS-TS model on the IPS learning of cooperative material in class IV, SDN 1 Karanganom, Tulungagung can be seen from the improvement on teacher activity and student activity. The syntax that has been implemented agreed with the syntax model of TS-TS model proposed by Huda (2013: 207-208), namely: (1) the teacher divides the students into groups (each group consists of 4 students), (2) the teacher delivers the sub-chapters to each group, (3) the students work together in the groups of four, (4) after finishing the discussion of sub-chapters that will be delivered to the guests, two people from each group leave the group and visit another group, (5) two people who are left in the group have the duty to share their work and information to the guests from other groups, (6) the guests excuse themselves and return to their own groups to report what they found/got from other groups in the form of discussion results, (7) the group members match and discuss their work results, (8) each group present their work in front of the class.

Cycle I obtained data that teacher activity has been appropriate with the syntax of TS-TS learning model, but it has not run optimally. The teachers have not implemented some descriptors that have been in syntax learning model. It can be seen from the observation of teacher activity achieved $87 \%$ in meeting, and then increased to $93 \%$ in meeting 2 , while the observation of student activity was $80 \%$, then increased to $87 \%$ at meeting 2 .In the first cycle, students' activities have improved compared to the learning activities in the preliminary study, students tend to be enthusiastic and active when learning although they were not yet maximal. But, the noise in the classroom was still happened. Students' interest was high about the model of learning applied by their teacher. It can be seen from the student's responsibility arised when they acted as the guest to write information for their own group, and the students who played as the host were responsible to convey the information to the guests. The ability of the students in doing the tasks given by teachers both in groups and individuals is sufficient, although there are still many students whose value is less than or below the KKM.

Cycle II obtained data that the teachers can manage and condition the class by implementing the learning model, it can be seen from the observation on teacher activity that achieved $93 \%$ in meeting 1 , and then increased to $100 \%$ at the meeting 2 . Percentage of success of the teacher activity has shown that teachers can implement learning IPS 
about cooperative materials using Two Stay-Two Stray model optimally. While on the second cycle, the results of observation on the student activity reached $87 \%$, and then increased to $93 \%$ in the meeting 2 . In cycle II, students have understood in depth about the steps of TS-TS model, so that learning process goes well and smoothly, the courage of students when presenting the results of the discussion is also high, all students are mostly active and enthusiastic in participating the learning activities. Students can work well with the group, so that the student activity also increased, and the number of students whose complete grade has also increased. Thus, it can be said that learning IPS about cooperative material through theTS-TS model is successful, and it has a good effect on the learning activity to the students of class IV, in SDN 1 Karanganom, Tulungagung, because it has increased many aspects.

Overall, the implementation of Two Stay-Two Stray model on learning IPS about cooperative material in the class IV, in SDN 1 Karanganom provides many benefits to the students since it can trigger the students to be more active, responsible, and learn to discuss with other students, also it enable them to exchange information with other groups, so that they can increase the activity with others, not only with its own group. According to Shoimin (2014: 225), the benefits of the TS-TS model are (1) more oriented to activeness/liveliness, (2) expected the students to be confident to express their opinions, (3) increase students' solidarity and confidence, and (4) students' speaking skill can be improved. Thus it can be proved that the implementation of TS-TS model can improve student learning activities.

Based on the observation result on teacher and student activity, it can be concluded that the implementation of TS-TS model on learning IPS about cooperative material of class IV in SDN 1 Karanganom has increased. This is proved by the results of observations on teacher activity and student activity in the cycle 2, meeting 2 . The observation results of teacher activities achieved $100 \%$, while the observation of student activity was $93 \%$.

The Improvement of Social Science Learning about Cooperative Material through Two Stay Two Stray Model on Students' outcomes of Class IV, in SDN I Karanganom, Tulungagung

Students' learning outcomes on learning IPS about cooperative material through the TSTS model in class IV, SDN 1 Karanganom, Tulungagung, increased. It can be seen from the improvement of students' learning outcomes from the learning activities in preliminary study, cycle I to cycle II. In the preliminary study obtained 63 of the average grades of classical (completeness 19\%).

In the first cycle of meeting 1, the average grade of classical was 63 (completeness of $31.25 \%$ ), it means that 5 students completed and 11 students did not complete. In the second meeting has increased, the average grade of classical was 69 (completeness of $56.25 \%$ ), it means that 9 students completed and 7 students did not complete. Based on the explanation, it can be concluded that the students' learning outcomes in learning IPS by the material of cooperative through TS-TS model has increased.

In the second cycle, students' learning outcomes also increased. In the meeting 1 , the average grade of classical was 72 (completeness of 68.75\%), it means 11 students completed and 5 students did not complete. In the meeting 2, the students' learning outcomes has increased, the average grdae of classical was 79 (completeness of $87.5 \%$ ), it 
means 14 students completed and 2 students did not complete. Based on the data explanation, it is concluded that the students' learning outcomes in learning IPS about cooperative material through the Two Stay-Two Stray model has increased and reached the completeness of classical learning with the percentage of completeness $87.5 \%$.

Sudjana (2009: 3) admitted that student learning outcomes are essentially behavioral changes. The behavior of learning outcomes in this definition includes the cognitive, affective, and psychomotor. Cognitive field is about knowledge, affective field is about attitudes, and psychomotor field is about skills. In this study, students' learning outcomes include the aspects of knowledge, attitudes, and skills of students during learning IPS about cooperative material through TS-TS model has increased.

Based on the data explanation, it found that classical completeness in cycle II has reached the KMK (Classical Minimum Completeness) which targeted to exceed 80\%, that was $87.5 \%$. Trianto (2012: 241) stated that classical success is said to be successful if the grade of students classically achieves the specified standard to $\geq 80 \%$. Thus, it can be said that learning is categorized as complete and not complete, then continued to the next cycle. As mentioned by Shoimin (2014: 225) that one of the advantages of TS-TS model on the order of 10 is "help to increase interest and learning achievement". Thus it can be said that the TS-TS model proved to be implemented to improve student learning outcomes in learning IPS by the material of cooperative. It agrees with the research of Diyan Krisnawati in 2015 about the improvement of learning IPS through the Two Stay-Two Stray model about kinds of occupations in class III, in SDN Kolomayan 02, Blitar.

\section{Conclusion}

The implementation of Two Stay-Two Stray model can be applied to learn IPS by the material of cooperative, because it can increase the teachers and students activity. It can be seen from the observation upon the teacher and student activity. In teacher activity, cycle I meeting 1 , the percentage of success achieved $87 \%$, and then in meeting 2 , it increased to $93 \%$. In the second cycle of meeting 1 , the percentage of success was $93 \%$, then in meeting 2 increased to $100 \%$ and reached the maximum. And for the student activity, in the first cycle of meeting 1 , the percentage of success achieved $80 \%$, and then in the secons meeting increased to $87 \%$. In cycle II meeting 1 , the percentage of success was $87 \%$, and then in the second meeting increased to $93 \%$.

IPS learning about cooperative material through Two Stay-Two Stray also proved to improve student learning outcomes. In the preliminary study, the average grade of calssical was 63 with a percentage of $19 \%$ completeness. In the first cycle of meeting 1 , the average grade of classical was 63 with the percentage of $31.25 \%$ completeness. In the first cycle of meeting 2, the average grade of classical increased to 69 with a percentage of $56.25 \%$ completeness. In the second cycle of meeting 1 , the average grade of classical increased to 72 with the percentage of $68.75 \%$ completeness. In the second cycle of meeting 2, the average grade of classical increased to 78 with the percentage of $87.5 \%$ completeness.

Some of the following suggestions are expected to improve and build the quality of learning, especially in learning IPS of class IV in SDN 1 Karanganom, Tulungagung. 
Teachers should apply the Two Stay-Two Stray model either to the learning of social science or other lessons since it is appropriate to the conditions of classroom and learning materials. This learning model can be used as one of the alternative learning models applied by the teacher, because it has been proven to improve student learning outcomes such the data that has been explained. Teachers should also provide special or remedial counseling for the students who have not yet achieved complete learning. This learning model can also increase the activity, courage, responsibility, cooperation and speaking skills of students during the learning activities. In addition, innovative and creative learning models like this can trigger students' interest in learning, so that the students are enthusiastic to learn and improve, and it affect the students' learning outcomes as a whole.

The further researchers should be smart in choosing and applying the learning models that are fun, interesting, and able to encourgae the students to be active in learning activities such as Two Stay-Two Stray model, so that the students are more excited and happy in doing the learning activities. Chosing an appropriate and interesting learning model can avoid students to feel bored so that the learning outcomes can be achieved maximum.

\section{References}

Ahmadi, A. 2003. Hmu Sosial Dasar. Jakarta: Rineka Cipta.

Arikunto, S, dkk. 2010. Penelitian Tindakan Kelas. Jakarta: PT Bumi Aksara.

Huda, M. 2013. Model-Model Pengajaran dan Pembelajaran. Malang: Pustaka Pelajar. Shoimin, Aris. 2014. 68 Model Pembelajaran Inovatif dalam Kurikulum2013. Yogyakarta: Ar-Ruzz Media.

Sudjana, N. 2009. Penilaian Hasil Proses Belajar Mengajar.Bandung: Remaja Rosdakarya.

Suradisastra, Djodjo, dkk. 1992. Pendidikan IPS III. Jakarta: Departemen Pendidikan dan Kebudayaan Direktorat Jenderal Pendidikan Tinggi Proyek Pembinaan Tenaga Kependidikan. 